working force, ${ }^{167}$ and that seniority drives the most able men to other fields. ${ }^{108}$ But the vigor of this opposition was somewhat lessened by the tendency of seniority to stabilize the working force. ${ }^{169}$ The holder of even an unattractive job will think twice before abandoning it if abandonment means the loss of hard-earned seniority and perhaps the necessity of starting again at the bottom of the seniority ladder. And this reduction of labor turnover of course effects considerable economies for the employer by reducing the costs incident to the training of new men. ${ }^{170}$

The social effects of seniority are perhaps not altogether desirable. The stabilizing tendency of seniority may operate to stifle initiative, enterprise and self-reliance. In the process of crystallization of the social structure seniority tends to emphasize class distinctions; a man's permanent place threatens to become, in the long run, his "proper" place. The stability of employment engendered by seniority is likely to produce stereotyped patterns of occupation, environment, income and education, which stamp the man and impair his ability to shift from one social stratum to another. But developments like these would seem only to reflect more general prevailing trends.

\title{
MORTGAGES ON FUTURE CROPS AS SECURITY FOR GOVERNMENT LOANS
}

Although the crop mortgage has long been recognized as a basis of credit extension to farmers, the practical implications of this particular security device have recently assumed an unprecedented significance in view of the activities of the various federal agencies in charge of agricultural relief. ${ }^{1}$ These agencies, of which the Farm Security Administration ${ }^{2}$ is a notable

167: See Louisville \& N. R. R. v. Bryant, 263 Ky. 578, 584, 92 S. W. (2d) 749, 752 (1936).

168. (1936) 100 RaILway Age 846.

169. See The Sentority Rules of the Nathonal Agreenent, op. cit. supra note 1, at 6 et seq.; Federal Co-Ordinator of Transportation, op. cit. supra note 148, at 119.

170. See Douglas, Problem of Labor Turnover, (1918) 8 AMER. ECoN. REv. 306; Labor Turnover, 8 ENCYc. Soc. ScIEnCEs 709. Many employers now accept seniority as an established system. See note 6 , supra.

1. For an evaluation of the work of federal agencies in financing agriculture and for a description of their administrative structure, see Johnson, Short Term Farm Credit Situation in the United States (1935) 17 J. FARM Econ. 277; Murray, Farm Morlgages and the Government (1935) $17 \mathrm{~J}$. FARM Econ. 613; Preston, Our Farm Credit System (1936) $18 \mathrm{~J}$. FARM ECON. 673.

2. The Farm Security Administration was established on September 2, 1937, at which time its predecessor, the Resettlement Administration, was abolished. See N. $Y$. Times, Sept. 2, 1937, p. 6, col. 4; U. S. News, Sept. 6, 1937, p. 3, col. 2. The Resettle- 
example, have made numerous loans intended to alleviate the farmers' temporary economic distress. ${ }^{3}$ But, in obtaining security for their extensions of credit, the agencies are frequently handicapped by the fact that farm lands are often heavily encumbered with debt and hence afford little security for additional obligations.4 Since the farmer may thus have no present unencumbered property interest which he can put up as security for the advance, the government must frequently rely upon a mortgage on the crop which the borrower intends to cultivate with the proceeds of the loan. ${ }^{5}$ Because of the diffculties which mortgagees have historically encountered in acquiring and enforcing crop mortgage liens, this reliance by the government on the crop mortgage device suggests an analysis of the various common law rules and statutory provisions upon which the modern crop mortgage is based in order to understand the problems confronting the federal agencies in connection with their extension of credit on the basis of this security device.

The initial problem facing the prospective crop mortgagee is whether or not he can secure his loan by a mortgage on property not yet in being. Although it has often been stated that mortgages on after-acquired chattels are void at common law, ${ }^{6}$ mortgages on future crops have generally been upheld 7 on various rationales. Thus, an exception to the common law rule has at times been found in the doctrine of "potential possession" by which a farmer is enabled to mortgage his interest in the products of his land and the increase of his herd. ${ }^{8}$ By this doctrine the mortgage is said to give the mortgagee an immediate interest in the chattels, which ripens into a legal lien once they have come into existence and is superior to any intervening claims that may have arisen since the original transaction. This doctrine, however, is seldom fully applied, even to the increase of animals or to the yield of perennial plants. ${ }^{10}$ Mortgages on future crops are more commonly upheld upon the theory that the creditor's loan, made in reliance on the debtor's promise to mortgage personal property, subsequently to be acquired, gives rise to an equitable lien on

ment Administration was set up on April 30,1935, by Executive Order of the President, No. 7027, under authority of the Emergency Relief Appropriation Act of 1935, 49 STAт. 115 (1935), 15 U. S. C. \$ 728, note (Supp. 1936).

3. The loans made by the Resettlement Administration alone for the years 1935-1936

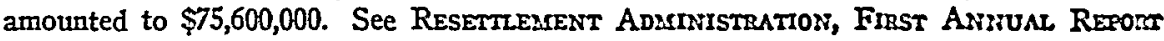
(1936) 4, 161-162.

4. Id. at 3.

5. See Resetrleareint Adninistration, Interiar Report (April 1936) 9.

6. WaLSH, MLoRtgages (1934) §10; Comment (1925) 34 Yale L. J. 175, 176.

7. 1 Jones, Ceatrez Morrgages and Conditional Sales (6th ed. 1933) $\S \S 143$, 170-174.

8. Michigan Sugar Co. v. Falkenhagen, 243 Mich. 698, 220 N. W. 760 (1928); see 1 Jowes, op. cit. supra note $7, \S 140 ;$ (1929) 14 Iows L. REv. 363. This doctrine stems from the English case of Grantham v. Hawley, Hob. 132 (1616). It has baen given considerable lip service by American courts.

9. 1 Wilitston, Sales (2d ed. 1924) $\$ \$ 133-136$.

10. See Comment (1924) 10 VA. L. REv. 393, 394. 
the property as soon as it comes into being. ${ }^{11}$ There is, however, a substantial divergence of opinion as to the nature and scope of the equitable interest thereby created in the crop mortgagee. In some jurisdictions, the crop mortgagee obtains a priority as against all but purchasers and encumbrancers who have given value without actual or constructive notice of the mortgage, ${ }^{12}$ while, in others, the mortgage lien is of no avail as against liens which have attached before the mortgagee has taken possession of the mortgaged crops. ${ }^{13}$ At least one state denies all practical effect to such transactions by holding that the mortgagee obtains merely a revocable license to enter and take possession of the mortgaged property, and that the mortgagor can avoid this license at will. ${ }^{14}$ In many states the status of the crop mortgagee has been clarified by statutes which expressly permit mortgages on future crops but which often restrict the scope of the lien to crops planted within one year of the mortgage date. ${ }^{15}$

Even in those states which afford the most complete protection to mortgage liens, however, the mortgagee who has not taken possession of the crop can never prevail over subsequent purchasers and encumbrancers who have no notice of the mortgage, unless the instrument is recorded. ${ }^{10}$ Such recording is generally deemed to give constructive notice of the lien, whether the crop is planted or unplanted, ${ }^{17}$ and even after it has been severed from

11. Walsh, op. cit. supra note 6, $\S 8$; Williston, Transfers of Aftcr-Acquired Pcrsonal Property (1906) 19 Harv. L. Rev. 557, 559. The leading case in the field is generally said to be Holroyd v. Marshall, $10 \mathrm{H}$. L. Cas. 191 (1861).

12. Bodenhamer v. Pacific Fruit \& Produce Co., 50 Idaho 248, 295 Pac. 243 (1931), (1931) 1 Idatro L. J. 192; Wheeler v. Becker, 68 Iowa 723, 28 N. W. 40 (1886).

13. First Nat. Bank v. Felter, 65 Colo. 370, 176 Pac. 496 (1918) ; Holt v. Lucas, 77 Kan. 710, 96 Pac. 30 (1908). Under the New York rule, duly recorded mortgages of after acquired property are valid against subsequent purchasers [Kribbs v. Alford, 120 N. Y. 519, 24 N. E. $811(1890)$ ] but not against creditors who have acquired a lien on the mortgaged chattels before the mortgagee has taken possession. Rochester Distilling Co. v. Rasey, 142 N. Y. 570, 37 N. E. 632 (1894). See Stone, The Equitable Mortgage in New York (1920) 20 CoL. L. Rev. 519; Comment (1929) 3 St. JorN's L. Rev. 139.

14. Kohler Improvement Co. v. Preder, 217 Wis. 641, 259 N. W. 833 (1935), (1936) 11 WIs. L. REv. 285. In Nebraska, future crop mortgages are ineffective even as between the parties in the absence of an intervening act. Brown v. Neilson, $61 \mathrm{Neb} .765$, 86 N. W. 498 (1901); see Ginsburg, Mortgages of After Acquired Personalty in Nebraska (1933) $11 \mathrm{NEB}$. L. BuLL. 289, 299-302. In North Dakota mortgages on growing and unharvested crops were recently abolished as a nuisance and as being against public policy. N. D. Laws 1933 , c. 150.

15. See, e.g., Ill. Rev. Stat. (1937) c. 95, § 1a; Ind. Stat. Ann. (Burns, Supp. 1937) §51-501; Mont. Rev. Codes AnN. (Anderson \& McFarland, 1935) §8290. Even in the absence of statute, it has been held that an unlimited grant of future crops is invalid. Shaw v. Gilmore, 81 Me. 396, 17 Atl. 314 (1889).

16. 1 JoNEs, op. cit. supra note $7, \S \S 157,170,190$.

17. Whaley v. Bright, 189 Ala. 134, 66 So. 644 (1914); First Nat. Bank v. Johnson, 221 Mo. App. 31, 297 S. W. 724 (1927); see Note (1932) 77 A. L. R. 572. For a summary of the statutory requirements of each state, see 1 JonEs, op. cit. supra note 7 , 
the land, ${ }^{18}$ although, of course, in those states which do not recognize the validity of the crop mortgagee's lien as against third parties, recording of the instrument will not of itself validate a mortgage. ${ }^{19}$ An exception to the theory of constructive notice is sometimes found in the distinction between annual and perennial crops such as fruit, since recordation of the latter as a chattel mortgage is occasionally held not to afford valid notice on the theory that such crops may be considered as part of the realty until severed from the land $;^{20}$ but the better view recognizes fruit as the product of human labor and considers it personalty while still growing. ${ }^{21}$ In any case, record notice of crop mortgage liens is of limited duration, for it has been the general practice to require such mortgages to be refiled within a prescribed period of time, ranging from one to three years.?

The further problem of who may mortgage a future crop is particularly complex because of the various requirements of interest which the courts have prescribed. Thus, it has often been said that the mortgagor must have some interest in the land upon which the crop is to grow at the time the mortgage is made, but what the nature and extent of this interest must be seems to depend largely upon the particular rationalization which the court has adopted to support the crop mortgage itself. In some jurisdictions a present interest as owner or tenant is usually required, since otherwise there could be no potential possession of the crop. ${ }^{23}$ In most jurisdictions, where the equitable lien theory is in force, the mortgagor need only contemplate acquiring an interest in the land, but the mortgage must contain an accurate description of the property so that the mortgaged crop may be identified and the

\$§ 190-235; Hanna, Exterusion of Public Recordation (1931) 31 CoL. L. REv. 617, 638641.

18. Truss v. Harvey, 120 Ala. 636, 24 So. 927 (1898); Wolf v. Cariton Bros., 10 S. W. (2d) 200 (Tex. Civ. App. 1928) ; Ino. Stat. A:ss. (Burns, Supp. 1937) § 51-518; Wyo. Rev. Stat. ANN. (Courtright, 1931) $\$ 71-129$. In some cases, the lien is only effective while the crop remains on the mortgagor's land. Brande v. Babeoct: Hardware Co., 35 Mont. 256, 88 Pac. 949 (1907); see CaL. Cr. Cone (Deering, 1931) \$2972.

19. American State Bank v. Keller, 112 Neb. 761, 200 N. W. 999 (1924); Rochester Distilling Co. v. Rasey, 142 N. Y. 570, 37 N. E. 632 (1894).

20. Nicholson v. People's Nat. Bank, 119 Okla. 113, 249 Pac. 336 (1926). This difficulty has been obviated by many recent statutes which provide that chattel mortgages may be given on both annual and perennial crops. See, c.g., KAw. Gex. Srsr. ANN. (Corrick, 1935) §58-322; Mass. ANN. Laws (Lawyer's Co-op., Supp. 1936) c. $255, \S 7 \mathrm{~A}$.

21. Congdon v. Wagner \& Sons, 207 Cal. 373, 278 Pac 863 (1929); Twin Falls Bank \& Trust Co. v. Weinberg, 44 Idaho 332, 257 Pac. 31 (1927), 54 A. L. R. 1532 (1928).

22. See, e.g., Mich. Acts 1935, no. 129, § 13427; Utar Rev. Stat. Ariz. (1933) \$13-0-2.

23. Moring v. Helms, 210 Ala. 175, 97 So. 647 (1923), (1924) 37 Hanv. L. REv. 765 ; Louisville Joint Stock Land Bank v. Watts, 251 Ky. 832, 66 S. W. (2d) 39 (1933) ; Comment (1924) 10 VA. L. REv. 393, 395. 
intentions of the parties ascertained. ${ }^{24}$ Moreover, the prospective mortgagor must have more than an actual or prospective interest in the land, for he must also have an interest in the mortgaged crop itself. Hence a landlord may not mortgage the crop of his tenant ${ }^{25}$ unless he has a fixed interest in a specific part of it, as is often true of the crop-sharing relation. ${ }^{26}$ And although a tenant will usually have sufficient interest in a crop to be raised by him, ${ }^{27}$ problems frequently arise when title to the crops is reserved to the landlord by the terms of the lease. ${ }^{28}$ Under such a lease, a proper lesseemortgagor would appear to be one who could not be ousted before the end of the term if all of his covenants were properly performed. ${ }^{20}$ Thus, a servant receiving wages in the form of a share in the crop would not be entitled to mortgage it. ${ }^{30}$ A possible solution of the crop-sharing problem is suggested by an Alabama statute which declares that, whenever one person furnishes the land, another the labor, and the crop is divided, a landlord-tenant relationship with all its incidents shall be deemed to exist. ${ }^{31}$

The concept that an interest in the crop is essential to the validity of a mortgage thereon is usually not satisfied by a mere potential interest at the time the mortgage is made. Because of the generally accepted rules that mortgages of after-acquired crops create no lien upon the land and that a lien attaches to the crops only when they come into being, and then only to such interest as the mortgagor has therein, it is necessary that the crops shall actually be grown and that the mortgagor shall retain his interest at least until that time. ${ }^{82}$ The effect of this rule is to place the mortgagee peculiarly at the mercy of his crop mortgagor, whose failure to plant the crop will inevitably destroy the mortgage security. ${ }^{33}$ Furthermore, when the mortgagor owns the land, ter-

24. Iverson v. Soo Elevator Co., 22 S. D. 638, 119 N. W. 1006 (1909); Richardson v. Washington, 88 Tex. 339, 31 S. W. 614 (1895); Community State Bank v. Martin, 144 Wash. 483, 258 Pac. 498 (1927); see Hogan v. Atlantic Elevator Co., 66 Minn. 344, 347,69 N. W. 1,2 (1896).

25. First Nat. Bank v. Crawford, 227 Ala. 188, 149 So. 228 (1933); Knaebel v. Wilson, 92 Iowa 536, 61 N. W. 178 (1894); Williams v. King, 206 S. W. 106 (Tex. Civ. App. 1918).

26. American Trust \& Savings Bank v. Whitaker, 2 S. W. (2d) 356 (Tex. Civ. App. 1928) ; see Bowyer v. Beardon, 291 S. W. 219, 222 (Tex. Comm. of App. 1927); cf. Devereaux Mortgage Co. v. Walker, 46 Idaho 431, 268 Pac. 37 (1928).

27. Farmers' \& Merchants' Nat. Bank v. Howell, 268 S. W. 776 ('Tex. Civ. App. 1925); 1 JoNes, op. cit. supra note $7, \S 141$.

28. This reservation may be held a chattel mortgage and required to be recorded as such. Farmers' State Bank v. Benston, 29 F. (2d) 902 (C. C. A. 8th, 1928) ; Joecleel v. Gust, 217 Mo. App. 495, 268 S. W. 888 (1925) ; cf. Wilcox \& Co. v. Deines, 119 Neb. 692, 230 N. W. 682 (1930). Contra: Merchants' State Bank v. Sawyer Farmers' Cooperative Ass'n, 47 N. D. 375, 182 N. W. 263 (1921).

29. Minneapolis Iron Store Co. v. Branum, 36 N. D. 355,162 N. W. 543 (1917); see (1931) 9 NEB. L. BuLI. 347 (distinction between tenant and cropper).

30. Booher v. Stewart, 75 Hun. 214, 27 N. Y. Supp. 114 (5th Dep't 1894).

31. Ala. Code ANN. (Michie, 1928) $\$ 8807$.

32. 1 Jones, op. cit. suprce note $7, \$ 143 \mathrm{a}$.

33. First Nat. Bank v. Brashear, 200 Cal. 389, 253 Pac. 143 (1927). 
mination of his interest therein by death, ${ }^{34}$ foreclosure, ${ }^{35}$ lease, ${ }^{30}$ or sale ${ }^{37}$ will also terminate his interest in the crop and will hence vitiate the mortgage itself unless the crop was in being and the lien had attached prior to the change of possession. ${ }^{38}$ It is possible, however, that a contrary result could be reached in most of these situations through a rigid adherence to the doctrine of "potential possession" on the ground that a present interest in the future crops, superior to all subsequent claims, passes to the mortgagee upon the execution of the mortgage. ${ }^{30}$ Where the mortgagor is merely a tenant, the security afforded by a crop mortgage is even more uncertain, since the tenant in certain instances may lose his right to the crop, and thus destroy his mortgagee's security, even after the crop has been planted. While ordinarily a lessee is permitted to enter after the termination of his lease to harvest a crop he has previously planted, ${ }^{40}$ the doctrine of emblements, upon which this right is based, does not apply when the contract is terminated through the fault of the tenant, as by default in the payment of rent, ${ }^{11}$ or abandonment, or surrender of the land. ${ }^{43}$

A somewhat analogous problem arises in the event of a conflict between a land and a crop mortgagee since the security of the crop mortgage must certainly fail when foreclosure of the land mortgage effects a change of possession before the mortgagor has planted his crop. ${ }^{44}$ But whether the crop mortgagee's security is also destroyed by a foreclosure of the land mortgage,

34. Fawcett Investment Co. v. Rullestad, 218 Iowa 654, 253 N. W. 131 (1934), (1935) 48 HARv. L. REv. 123.

35. Louis v. Hansen, 205 Iowa 1216, 219 N. W. 523 (1928) ; cf. Zeigler v. Citizens' Bank of Venus, 79 S. W. (2d) 662 (Tex. Civ. App. 1935) (sale of future crops).

36. MicMaster v. Emerson, 109 Iowa 284,80 N. W. 389 (1899); Isbell v. Slette, 52 Mont. 156, 155 Pac. 503 (1916) ; cf. Daniel v. Clayton \& Co., 25 Ala. App. 497,149 So. 355 (1933) (mortgagor sold land but grew the crop as tenant of his grantes, and crop mortgage upheld).

37. Snerly v. Stacey, 174 Ark. 978, 289 S. W. 213 (1927). It seems that the mortgagee could provide against this contingency by obtaining, along with the crop mortgage, an assignment of rents in case the crop should be raised by a tenant. Furthermore, it can be argued that actual notice of the mortgage should render the mortgagor's land grantee or tenant liable for inducing a breach of contract.

38. Congdon v. Wagner \& Sons, 207 Cal. 373, 278 Pac. 863 (1929) ; N. Bar N. Land \& Livestock Co. v. Taylor, 94 Mont. 350, 22 P. (2d) 313 (1933).

39. State Bank v. St. Anthony \& Dakota Elevator Co., 54 N. D. 264, 209 N. W. 351 (1926) (lease of land prior to planting of crops did not destroy mortgage lien); see (1935) 48 HARV. L. REv. 123.

40. It is often said that this doctrine only applies where the term was uncertain. Commonwealth v. Galatta, 228 Miass. 308, 117 N. E. 343 (1917); see Jordan v. Dinwiddie, 205 S. W. 862,863 (Tex. Civ. App. 1918).

41. Societa Italiana di Mutua Beneficenza v. Burr, 71 F. (2d) 496 (C. C. A. 9th, 1934) ; Francis Bros. v. Schallberger, 137 Ore 529, 3 P. (2d) 530 (1931), 83 A. L R. 114 (1933).

42. Taack v. Underwood, 266 S. W. 618 (Tex. Civ. App. 1924).

43. Third Nat. Bank v. Kniffen, 143 Wash. 434, 255 Pac. 378 (1927).

44. See note 35 , supra. 
subsequent to the planting, seems to depend upon varying interpretations of the nature and extent of the land mortgagee's lien. It is a general rule that, stipulations in the mortgage notwithstanding, a land mortgagee has no right to the rents and profits from the mortgaged property until he acts to reduce them to possession. ${ }^{45}$ Therefore, a crop mortgagee who forecloses after the crop has been planted but before the land mortgagee has obtained possession would undoubtedly prevail against the land mortgagee. ${ }^{46}$ When the land mortgagee forecloses first, however, the decisions are divided as to which lien shall have priority. In those jurisdictions which hold that the land mortgagee obtained no lien upon the unsevered crop prior to the foreclosure, his lien will be subordinate to that of a crop mortgagee whose lien attached as soon as the crop came into existence. ${ }^{47}$ But when the land mortgagee's lien is deemed to include both the land and the crops growing thereon in the first instance, the crop and land mortgage liens will have attached simultaneously upon the planting of the crop, and in such a case the crop mortgagee's lien will be protected only if his mortgage was executed and recorded prior to that of the land mortgagee. ${ }^{48}$ In determining at what point the land mortgagee obtained a lien upon the crop, the majority of courts do not consider the inclusion of a rents and profits clause as significant, ${ }^{40}$ although in a few jurisdictions the presence of such a clause is held to be of controlling importance. ${ }^{50}$ This question has been specifically dealt with by an Iowa statute which permits the indexing of land mortgages containing rents and profits clauses in the chattel mortgage records. ${ }^{51}$ It seems, however, that this element

45. Teal v. Walker, 111 U. S. 242 (1884); 2 Jones, Mortgnges (8th ed. 1928) § 975-976; Comment (1928) 76 U. of PA. L. REv. 851, 853; Note (1933) 91 A. L. R. $1217,1225$.

46. See In re Schilling, 251 Fed. 972, 974 (N. D. Ohio 1918); 1 JoNEs, op. cit. supra note $7, \S 178$. It has been held that a junior mortgagee who takes possession of the property is entitled to the rents and profits as against the senior mortgagee, at least until the latter has asserted his rights by obtaining the appointment of a recciver. Lynch v. Donahoe, 205 Iowa 537, 215 N. W. 736 (1927); Sullivan v. Rosson, 223 N. X. 217, 119 N. E. 405 (1918).

47. First Nat. Bank v. Garner, 91 Cal. App. 176, 266 Pac. 849 (1928); Southern Trust Co. v. First City Bank \& Trust Co., 259 Ky. 151, 82 S. W. (2d) 205 (1935) ; Kirby v. First Nat. Bank, 131 Wash. 204, 229 Pac. 305 (1924); Note (1927) 47 A. L. R. 772.

48. Thompson v. Union Warehouse Co., 110 Ala. 499, 18 So. 105 (1895); Buchmann v. Callahan, 222 Ala. 240, 131 So. 799 (1931); John Hancock Mutual Life Insurance Co. v. Watson, 200 Ill. App. 315 (1916) ; see Equitable Life Insurance Co. v. Read, 215 Iowa 700, 703, $246 \mathrm{~N}$. W. 779, 780 (1933).

49. See Notes (1919) 4 A. L. R. 1405, 1410, (1928) 55 A. L. R. 1020, 1022.

50. Wilson v. Draper, 9 Ala. App. 585, 63 So. 779 (1913); Treat v. Dorman, 100 Cal. 623, 35 Pac. 86 (1893) ; see Anderson v. Marietta Nat. Bank, 93 Okla. 241, 243, 220 Pac. 883, 884 (1923) ; Notes (1933) 87 A. L. R. 625, 631, (1934) 91 A. L. R. 1217, 1225.

51. Iowa CODE (1935) $\$ 10032$. It was found that the policy of allowing the land mortgage lien to attach only upon foreclosure encouraged mortgagors in distress to lease and assign the rents just prior to the foreclosure proceedings. See Equitable Life. Insurance Co. v. Brown, 220 Iowa 585, 592, 262 N. W. 124, 128 (1935). 
of insecurity in crop mortgages could be obviated in all instances by means of agreements whereby the land mortgagee would subordinate his interest in the crop to that of a crop mortgagee who might, therefore, extend further credit to the mortgagor. ${ }^{52}$ The right of a crop mortgagee to enforce his lien on the crops against one who has purchased the land at foreclosure sale is also dependent upon the scope of the land mortgagee's lien, for if this lien is held to include the unsevered crops in the first instance, the purchaser at the sale will take a valid title thereto as against the crop mortgagee. ${ }^{33}$

The voluntary bankruptcy ${ }^{54}$ of the crop mortgagor raises still further problems-including the question of whether a mortgage lien on an unplanted crop is affected by the discharge of the bankrupt. In general, it may be said that valid liens given for a present consideration are not affected by such a discharge, ${ }^{55}$ but since it is generally held that no crop mortgage lien exists before the planting of the crop, ${ }^{50}$ there is nothing to survive a discharge in bankruptcy which occurs prior to that time, ${ }^{5 T}$ and no lien may arise thereafter, for there is then no debt to support it. ${ }^{53}$ A different result has been reached in North Dakota, however, through adherence to the doctrine of potential possession, whereby the mortgage is said to create a present lien on a future crop which will survive the intervening discharge of the mort-

52. The statutory priority accorded by some states to landlords' and laborers' liens could be similarly dealt with. Mfany recent statutes provide for the recordation of subordination agreements. See, c.g., Ixd. Stat. ANN. (Burns, Supp. 1937) \$ 51-512; Mass. Ann. Laws (Lawyer's Co-op., Supp. 1936) c. 255, §7d. See note 91, infro.

53. Penryn Co. v. Sherman-Worrell Co., 142 Cal. 643, 76 Pac. 484 (1904); Jones v. Adams, 37 Ore. 473, 59 Pac. 811 (1900); MfcCormick v. Terry, 147 Va. 448, 137 S. E. 452 (1927) ; 3 Trffany, Real Property (2d ed. 1920) $\$ 613 \mathrm{~b}$.

A different result is reached in those jurisdictions which hold that a crop mortgage works a constructive severance of the crop from the realty and removes it from the purview of the land mortgage as effectively as would a physical severance. Tolland Co. v. First State Bank, 95 Colo. 321, 35 P. (2d) 867 (1934); Hughes v. Summit Realty Co., 120 Fla. 136, 162 So. 343 (1935); Red River Nat. Bank v. Summers, 30 S. W. (2d) 726 (Tex. Civ. App. 1930).

Another element of insecurity to crop mortgagees is to be found in statutes granting liens on the crops to landlords [see, e.g., ArA. CODE ANr. (MTichic, 1925) \$8799; MIss. Cone Ann. (1930) §2186] and to laborers. See, c.g., Mlorrr. Rev. Cones Axzi. (Anderson \& MicFarland, 1935) $\$ \S 8369,8374.1$.

54. Farmers are exempted from involuntary proceedings by $\$ 4$ b of the Banl:ruptcy Act, 30 Stat. 547 (1898); 11 U. S. C. $\$ 22$ b (1934).

55. Bankruptcy Act $\$ 67$ d, 30 StAT. 564 (1898), 11 U. S. C. $\$ 107$ d (1934); see generally, 4 ReMtington, BankRurtcy (4th ed. 1935) $\$ \S 1943-1953.50$.

56. See note 32, supra.

57. Sims v. Jamison, 67 F. (2d) 409 (C. C. A. 9th, 1933). State law governs the nature and validity of mortgage transactions, and when the lien attaches. Thompson v. Fairbanks, 196 U. S. 516 (1905); MLason v. Citizens' Nat. Banls, 71 F. (2d) 246 (C. C. A. 9th, 1934).

58. Butler Cotton Oil Co. v. Collins, 200 Ala. 217, 75 So. 975 (1917). 
gagor. ${ }^{59}$ The incidence of bankruptcy may also be peculiar to future crop mortgages when an insolvent mortgagor plants the crop within four months of the filing of the petition, although the instrument itself was executed and recorded prior to that time, for it may be argued in such a case that the planting of the crop constitutes a voidable transfer within the meaning of Section $60 \mathrm{~b}$ of the Bankruptcy Act. ${ }^{60}$ It has been held in this situation, however, that the lien relates back to the mortgage date and is valid accordingly. ${ }^{\text {BI }}$ This result seems sound since there is little cause for holding that a preferential transfer occurs at this point. ${ }^{62}$ The mere planting of a crop, not theretofore among the assets of the bankrupt, should not be said to constitute a depletion of his estate. ${ }^{63}$ Moreover, the planting of the crop within the four months period should raise little question of invalidity because of an intent to hinder, delay or defraud creditors, i.e., intent implicit in the transaction itself, even though the loan made with the execution of the mortgage might then fail to qualify as "present" consideration. ${ }^{04}$ The trustee, who under Section 47 a (2) occupies the position of a lien creditor as to all property in the custody of the bankruptcy court and that of a judgment creditor with execution returned unsatisfied as to all other property of the bankrupt, ${ }^{65}$ would be unable to attack such a transfer, since he only occupies that position from the date when the petition is filed. ${ }^{.6}$ Nor would he fare better

59. Thompson Yards, Inc. v. Richardson, 51 N. D. 241, 199 N. W. 863 (1924), (1925) 19 Irr. L. Rev. 365; Union Nat. Bank v. Lenton, 54 N. D. 262, 209 N. W. 350 (1926), cert. denied, 275 U. S. 506 (1927) ; cf. Waters v. Ellington \& Co., 289 S. W. 417 (Tex. Civ. App. 1926) (crop planted after petition but before discharge).

60. 30 Stat. 562 (1898), 11 U. S. C. $\$ 96 \mathrm{~b}$ (1934). This is on account of the prevailing view that no lien arises until the crop is in being. See note 32, supra.

61. Moccasin State Bank v. Waldron, 81 Mont. 579, 264 Pac. 940 (1928) ; cf. Thompson v. Fairbanks, 196 U. S. 516 (1905). In defense of this position, see WALsu, op. cit. supra note $6, \$ 12$.

62. Preferential transfers made within the four months period are voidable by the trustee under the conditions specified in $\S 60 \mathrm{~b}, 30$ STAT. 562 (1898), 11 U. S. C. $\$ 96 \mathrm{~b}$ (1934). A "transfer" is defined to include the actual mortgage transaction by $\S 1$ (25), 30 STAT. 544 (1898), 11 U. S. C. $\$ 1$ (25) (1934). And a preference given by a farmer, though he is exempt from involuntary bankruptcy, may be avoided by his trustee appointed in a voluntary proceeding. Anderson v. Prosser, 157 Minn. 64, 195 N. W. 533 (1923).

63. There can be no preferential transfer unless the bankrupt parts with some of his property for the benefit of a creditor. Newport Bank v. Herkimer Bank, 225 U. S. 178 (1912) ; First Nat. Bank v. Live Stock Nat. Bank, 31 F. (2) 416 (C. C. A. 8th, 1929); see Gilmert's Collier, Bankruptcy (4th ed. 1937) § 1169. The slight extent to which the use of seed and fertilizer involves a depletion should not alter the result, especially when the mortgage is often an enabling loan for the purchase of these materials and may be favored as such. See Comment (1925) 34 YALE L. J. 891, 895.

64. Transfers with such intent are void as against creditors under Section $67 \mathrm{e}, 30$ Stat. 564, (1898), 11 U. S. C. §107e (1934). See Dodd v. Raines, 1 F. (2d) 658, 659 (N. D. Ga. 1924).

65. 30 Stat. 557 (1898), 11 U. S. C. $\S 75 a$ (2) (1934).

66. Bailey v. Baker-Ice Machine Co., 239 U. S. 268 (1915). 
as representative of the bankrupt's creditors, ${ }^{, 7}$ for no creditor armed with process could secure a prior lien when that of the mortgage attaches the moment that the crop comes into being.

The time of recording the mortgage is thus material in determining whether a preferential transfer has taken place. In those states which uphold the validity of mortgages upon future crops against the claims of third persons, the mortgagee remains entitled to his security when the mortgage is recorded and the crop planted prior to the four months period. ${ }^{08}$ Furthermore, the mortgage lien should always prevail as against the trustee where the instrument is recorded at the time when the loan is advanced, and the crop is planted prior to the discharge, since the Bankrupty Act preserves all liens given in good faith and for a present consideration. ${ }^{60}$ When a previously executed mortgage is recorded within the four months period, however, it will be open to attack as a voidable preference provided that before its recordation claims arose which under the local state law are entitled to priority. ${ }^{70}$ Moreover, it seems clear that the trustee in his several capacities will prevail over the crop mortgagee who fails to record his lien until after the petition in bankruptcy has been filed. ${ }^{11}$ When mortgages on future crops are invalid as against creditors, their recordation is wholly ineffective. ${ }^{72}$ Hence, any attempt

67. Bankruptcy Act $\$ \S 67 a, b, 70 e, 30$ STAT. 564,565 (1898), 11 U. S. C. $\$ \S 107 a, b$, $110 \mathrm{e}$ (1934).

68. Only preferences given or recorded within the four months period are voidable by the terms of $\S 60 \mathrm{~b}$. In re Spelman, 19 F. (2d) 138 (C. C. A. 8th, 1927) (despite fact that farmer, at request of creditor, refrained from filing petition until after four months from the mortgage date); cf. In re Pine Tree Lumber Co., 269 Fed. 515 (C. C. A. 9th, 1920); see 4 Rearrngton, op. cit. sitpra note 55, $\$ 1773$. Under $\$ 70$ (4) and a, 30 Stat. 565 (1898), 11 U. S. C. $\$ 110 \mathrm{a}$ (4) and e (1934), however, fraudulent transfers are not thus immune. Id. at $\S 1509$.

69. Lake View State Bank v. Jones, 242 Fed. 821 (C. C. A. 7th, 1917); In re Shepoka, 32 F. (2d) 1011 (D. Neb. 1929); Bankruptcy Act $\$ 67 d, 30$ Stıт. 564 (1898), 11 U. S. C. $\S 107 d$ (1934). There should be no question of a voidable preference under $\S 60 \mathrm{~b}$ when there is no pre-existing debt involved. See 4 Rensmotos, of. cil. sufro note $55, \S 1694$.

70. In re Custer, 55 F. (2d) 718 (S. D. Ohio 1931) ; Foltz v. Davis, 63 F. (2d) 495 (C. C. A. 7th, 1934); Note (1933) 83 A. L. R. 1279, 1284. Likewise where possession is taken under an unrecorded mortgage within the four months period. Haupt v. Moore, 77 F. (2d) 456 (C. C. A. 9th, 1935); Goldberg v. Brule Timber Co., 140 Alinn. 335, 168 N. W. 22 (1918).

When no creditor, under the local reccrding acts, has acquired a protected status against the mortgage lien prior to the filing of the petition, the trustee can assert no superior rights. In re Gibson, 65 F. (2d) 921 (C. C. A. 6th, 1933) (recordation within the four months period); Patnott v. Simpson, 35 F. (2d) 840 (C. C. A. 9th, 1929) (possession taken within the four months); see Comments (1916) 29 HAnv. L. REv. 766; (1935) 44 Y YIE L. J. 109.

71. Farmers' State Bank v. Beniton, 29 F. (2d) 902 (C. C. A. 8th, 1928). See 1 JoNEs, op. cit. supra note $7, \S 242$ 2-c; 4 Reanincrov, op. cit. supra note $55, \S 1563$. As to the several capacities of the trustee, see notes 65,67 , supro.

72. See note 19 , supra. 
to validate such transactions within the four months period, as by taking possession of the crops ${ }^{73}$ or by the substitution of a new instrument, ${ }^{74}$ may be avoided by the trustee. Renewal of a previously valid mortgage, however, by a new instrument of equal amount does not constitute a voidable preference even though the mortgagee was aware of the mortgagor's insolvency. ${ }^{75}$ Nor is refiling a valid mortgage a preferential transfer, unless effected after a mandatory period, ${ }^{76}$ when it may be ineffective to restore the status of the original mortgage as against the trustee. ${ }^{77}$ It may be noted that present mortgages given to secure future advances are not for that reason preferential, but are valid to the extent of the advances actually made. ${ }^{78}$

In view of the many obstacles which beset the crop mortgagee in the protection of his lien, it may be doubted whether the crop mortgage device will ordinarily afford adequate protection as security for a loan. But since the government has found it necessary to use this security device for purposes of relief, certain privileges have been afforded the federal agencies as crop mortgagees. Thus, many states have passed statutes designed to protect the crop mortgagee which are in many instances confined in their application to federal agencies and other institutions having access to their discount facilities. In a few states where crop mortgages are generally invalid as to creditors, an exception has been made for federal agencies. ${ }^{70}$ In others, they have been granted privileges not shared by the ordinary mortgagee. For example, at least one statute attempts to grant them a present lien on a future crop by the provision that their mortgages shall be effective at law from the date of recording as against the claims of subsequent purchasers and execution creditors. ${ }^{80}$ In several cases, the lien of the crop mortgage is made superior to that of any mortgage or judgment lien upon the land, although an exception is commonly made of those land mortgages which were recorded prior to the passage of the particular statute. ${ }^{81}$ The danger of perennial crops being considered realty and thus not the proper subject for a chattel mortgage is often obviated by the provision that they are to be considered personalty for

73. Grimes v. Clark, 234 Fed. C04 (C. C. A. 4th, 1916). The same is true when identification of the mortgaged chattels is completed within the four months period, since the lien is then created for the first time. First Nat. Bank v. Johnson, $68 \mathrm{Neb}$. 641, 94 N. W. 837 (1903).

74. Hayes v. Gibson, 279 Fed. 812 (C. C. A. 3d, 1922); In re Modell, 71 F. (2d) 148 (C. C. A. 2d, 1934).

75. Schreiber v. Colt, 80 F. (2d) 511 (C. C. A. 10th, 1935).

76. In re Dagwell, 263 Fed. 406 (E. D. Mich. 1920).

77. In re Active Wet Wash Laundry Co., 8 F. Supp. 964 (S. D. N. Y. 1934) (mortgage void after one year as against third persoss if not refiled).

78. In re Great Lakes Lumber Co., 8 F. (2d, 96 (W. D. Pa. 1925).

79. See, e.g., N. Y. LIEN LAw, art. 10 (1934); N. D. Laws 1933, c. 145; PA. Stat. (Purdon, 1936) tit. 21, §§ 931-935.

80. Conn. Gen. Stat. (Supp. 1935) \& 1591c.

81. See, e.g., Dez. Rev. Code (1935) § 3372; Mo. Code Pub. Local Laws (Flack, Supp. 1935) art. 21, § 54 B; Pa. Stat. (Purdon, 1936) tit. 21, § 931. 
the purpose of the statute and mortgageable as such. ${ }^{82}$ Upon default, the federal agency is also granted privileges special to itself. Under some statutes, it may then take possession of the mortgaged property without process of law and do all things necessary to preserve it, the expenses which are incurred thereby being included in and secured by the mortgage lien. ${ }^{83}$ In addition to the usual methods of foreclosure, the mortgage of the federal agency may sometimes be foreclosed in any manner arranged for therein as, for instance, by a power of sale. ${ }^{84}$ The extent of the lien is usually limited to crops that will be planted within one year of the mortgage date, ${ }^{85}$ and the mortgage itself must almost invariably be refiled within a prescribed time ranging from three to five years. ${ }^{86}$

In addition to the privileges granted it by the enabling statutes, the Farm Security Administration ${ }^{87}$ has resorted to further safeguards to protect its loans. In jurisdictions where mortgages on future crops are invalid as against creditors, the Administration often requires that the debtor promise in writing to execute a mortgage as soon as the crop comes into existence. ${ }^{83}$ It seems, however, that such an agreement would not affect the crop with a lien valid against third parties without notice, and consequently other liens which attached prior to the execution and recordation of the actual mortgage would enjoy priority. ${ }^{89}$ Moreover, where such a mortgage is executed within four months of the debtor's petition in bankruptcy, it should be open to attack by the trustee as a voidable preference, since there is no present con-

82. See, e.g., Mí. Code Pub. Local Laws (Flack, Supp. 1935) art. 21, \$ 54 A; PA. Stat. (Purdon, 1936) tit. 21, § 931.

83. See, e.g., Del. Rev. Cone (1935) §3372; PA. Stat. (Purdon, 1936) tit. 21, $\S 934$.

84. See, e.g., Mid. Code Pub. Local Laws (Flack, Supp. 1935) art. 21, $\S 54$ N; R. I. Laws 1935 , c. 2200, $\$ 6$.

85. See, e.g., Dex. Rev. Code (1935) §3366; Mín. Code Pop. Local Laws (Flacl; Supp. 1935) art. 21, \$54 A; N. H. Laws 1933, c. 43, \$1. In New Jersey, however, the lien may extend to any crops grown during the existence of the mortgage. N. J. Laws $1934, \S 4178$.

86. See, e.g., Conn. Gen. Stat. (Supp. 1935) §1591c; N. Y. Linn LaN, art. 10, $\S 7$ (1934) ; PA. STax. (Purdon, 1936) tit. 21, \$932.

The statutes generally provide that these mortgages may also secure future advances to be made at the option of the mortgagee, provided that they are made within a stipulated time and do not exceed an aggregate amount stated in the mortgage. See, c.g., Conn. Gen. Stat. (Supp. 1935) §1591c; Mid. Cone Pub. Locnl Lnws (Flacl;, Supp. $1935)$ art. $21, \S 54 \mathrm{C} ; \mathrm{N}$. J. Laws 1934, § 4-185. In the absence of such statutes, the courts are in conflict as to whether a mortgage can secure future advances against intervening liens in cases where the mortgagee is not obligated to make them. See 1 Jores, op. cir. supra note 7, \$\$ 94-98; WaLSH, op. cit. supra note $6, \S 15$.

87. See note 2 , supra.

88. For the form of agreement, see Stunges, Cases on Caedi Tansisactions (2d ed. 1936) 385. The Farm Credit Association has also made use of these agreements. Farm Credit Association, Form No. 1 (Miarch 1; 1934) 5.

89. Hayes v. Gibson, 279 Fed. 812 (C. C. A. 3d, 1922); In re Trat's Estate, 297 Fed. 458 (C. C. A. 8th, 1924). 
sideration to support the lien..$^{90} \mathrm{~A}$ more effective safeguard is to be found in the subordination agreements which the Farm Security Administration demands from all other lienors. ${ }^{91}$ These the Administration is in a particularly favorable position to obtain both because of its large credit facilities and because of its policy of lending to those farmers who are unable to secure credit from other sources $;^{92}$ the various lienors will often waive whatever rights they may have in a future crop, if the planting of that crop depends upon funds which the farmer can obtain only through a government loan. These subordination agreements should obviate the danger that liens which arose prior to the crop mortgage may be superior to it under local law, ${ }^{03}$ although, in those states which do not recognize the validity of crop mortgages as against third parties, they will not preclude the possibility of superior liens arising once the crop is in existence. ${ }^{94}$ But in the majority of states, where the recording of the mortgage makes it effective against all parties, these agreements should assure the security of the crop mortgagee. ${ }^{05}$

Because of the increase in crop production which the government's policy of credit extension to farmers will necessarily entail, ${ }^{96}$ it may, however, be questioned whether extensive use of the crop mortgage device is entirely desirable from an economic point of view-especially in the light of the government's policy of limiting production in order to assure higher and more stable prices for farm commodities.97 The reason for this apparent conflict of policies probably lies in the fact that the distress of many farm families has made some form of monetary relief imperative. ${ }^{98}$ But this conflict may be avoided in part, at least, by means of the farm plans which each prospective borrower from the Farm Security Administration agrees to follow

90. See note 74, supra.

91. For the form of the agreement, see STuRges, op. cit. supra note 88, at 387. Such agreements have also been made use of by the Farm Credit Administration in its crop financing activities. See U. S. Farm Credit Administration, loc. cit. stipra note 88. These agreements are strictly construed. Irvine v. California Cotton Credit Corp., 18 Cal. App. (2d) 761, 64 P. (2d) 782 (1937).

Most of the enabling statutes provide for the recordation of these agreements. See, e.g., N. H. Laws 1935 , c. 41, \& 3; N. J. Laws 1934 , § 4-180.

92. Resettlement Administration, op. cit. supra note 5, at 8-9.

93. See notes 48,53 , supra.

94. See notes 13,14 , supra.

95. See notes 17,18 , supra.

96. The Farm Security Administration makes grants to those farm families whose financial status is such as to make the repayment of loans unlikely and also purchases submarginal land, resettling the families who had been living there on more fertile soil. See ResettLement Administration, op. cit. supra note 3, at 3; Tugwell, Changing Acres (Sept. 1936) 44 CUR. Hrsr. 59-63. It seems evident that these activities will also increase crop production.

97. See Garrett, Plowring up Freedom (Nov. 16, 1936) 120 SAr. Ev. Posr 16, 70. Cf. President Roosevelt's "Fireside Chat" of October 12, 1937, N. Y. Herald Tribune, Oct. 13, 1937, p. 7, col. 3.

98. See Resettlemint Administration, op. cit. supra note 3, at 3. 